\title{
New Industrial Rights and Wrongs: the Changed Framework of British Employment Law
}

\section{John Goodman and Jill Earnshaw*}

This report outlines and assesses the substantial shifts in both collective and individual employment law in the United Kingdom since 1979. Against the background of a unique legal tradition and recent labour market trends, the paper summarises the step-by-step strategy of restricting trade union immunities in relation to industrial action, etc. It suggests that many new features, such as compulsory strike ballots, will survive a future change in political control. On employee statutory rights the direction of change has been less consistent. Major tensions are apparent between the Conservative Government's deregulatory instincts and both the standard-setting directives from the European Union and significant court judgments on issues such as equal opportunities and equal pay.

\section{Introduction}

This paper is intended to summarise the far-reaching changes which have taken place in employment law in Britain in the period since the election of the Conservative Government led by Mrs Thatcher in 1979. Conservative governments have held power in the United Kingdom continuously since 1979, and the reform of the law relating to trade unions has been a central priority throughout that period. The legislation has been radical, with a succession of statutes introduced incrementally at (approximately) two year intervals aimed principally at regulating and curtailing many of the historical freedoms of trade unions, particularly in relation to industrial disputes, the closed shop and internal governance. These policies have been consistent in their broad interventionist thrust, although the precise focus of the statutes at particular times has differed. In aggregate they have produced a structure of legal restraints on trade union behaviour which contrasts starkly with the traditional situation of relative abstentionism and "collective laissez-faire" that characterised this area for most of the present century (McCarthy, ed., 1992). In individual employment law the process and direction of change has been less simple, with the Conservative Government's early drive to reduce the statutory rights of individual employees, inherited from the predecessor Labour Government, being increasingly constrained and frustrated by new directives and judgments emanating from the European Union (EU).

For ease of exposition the paper has two principal sub-divisions, dealing first with collective and then with individual employment law. These are preceded by brief overviews of the broad historical characteristics of British employment law, and secondly some key features of the economic and social context in which the reforms have been introduced. 


\section{The traditional role of the law in British industrial relations}

Conventionally the system of industrial relations for much of the twentieth century was regarded as distinctive in internationally comparative terms, mainly in relation to the scope given to voluntary action by employers and trade unions, and the relative lack of involvement of the law (and lawyers) in peacetime. Trade union freedoms, for example, rested on a series of statutory immunities from the operation of civil law torts rather than on a framework of positive statutory rights. This status allowed many of the immunities to be criticised as "privileges", particularly during the 1960s and 1970s when it became increasingly common for the failings of Britain's relative economic performance to be attributed to "excessive" trade union power. Other key features of the British tradition were the absence of legal obligations on employers to recognise or bargain with trade unions representing their work forces, the lack of legal enforceability of collective agreements by the parties to them, the voluntary nature of third party intervention, e.g. conciliation and arbitration and the associated lack of compulsory powers available to governments in industrial disputes, short of the declaration of states of emergency. Perhaps surprisingly, given the imagery attached to the changes introduced since 1979, all these features remain.

State intervention in the setting of substantive minima and statutory employment rights o creating machinery for their enforcement was also minimal, being essentially confined to health and safety and a partial approach to minimum pay standards which applied only to areas of employment where the (preferred) system of collective bargaining had failed to develop. Prior to 1979, collective bargaining, whilst increasingly constrained in the 1960 and 1970s by successive governmental attempts to restrain wage and price inflation through a variety of incomes policies, was supported only by some indirect legislative props - such as the Fair Wages Resolution which set minimum standards on contractors to public authorities. Individual employment rights were also largely left to the contents of individual employment contracts and (where applicable) the provisions of collective agreements. This tradition was breached in the 1960 s when statutory rights were introduced in relation to minimum periods of notice of dismissal, statutory minimum compensation in the event of redundancy, in 1970 by the Equal Pay Act and in 1971 by the introduction of remedies for "unfair dismissal".

The system of industrial relations in Britain in the 1950s and 1960s was thus predominantly seen as being voluntarist, centred around the key institution of collective bargaining, which achieved a level of coverage significantly in excess of trade union membership. In the 1960s, increasing criticisms of the system, mainly in terms of unofficial strikes, workplace earnings drift and restrictive labour practices, led the then Labour Government to set up Royal Commission under Lord Donovan to examine the system and specifically to reviev the case for increased legal regulation. Its report in 1968 focused primarily on the failing effectiveness of multi-employer agreements (especially) in the manufacturing industry, an the need to reconstruct collective bargaining arrangements, largely through the creation of more formal structures and more comprehensive agreements at workplace or company levels. It proposed no major changes to the traditional legal framework, for example eschewing cooling-off periods, strike ballots and the legal enforceability of collective agreements, though it did propose legislation to protect employees against unfair dismissal Despite, or perhaps because of, its recommendations, subsequent proposals from both majo 
political parties for changes in the legal framework were at the centre of political controversy. The Conservatives' attempt to introduce a North American-style legal framework at a stroke through the 1971 Industrial Relations Act ignited huge trade union opposition, and early repeal by the incoming 1974-79 Labour Government as part of its neo-corporatist Social Contract with the unions. The subsequent Thatcher Government's policy of determined, but incremental legislation, introduced under an anti-corporatist, market-oriented and de-regulatory ideology, plainly owed much to the lessons of the 1971 approach. Whilst the unions have opposed each tranche of the legislative changes, for a variety of reasons their opposition has not been effective. Much of the early legislation,for example on picketing and compulsory pre-strike ballots, was electorally popular and its removal by a future Labour Government has ceased to be a practical proposition.

\section{The economic and social context}

The election of the first Thatcher Government in 1979 heralded a significant shift in the management of the British economy. The corporatist approach, attempted by predecessor governments, was rejected on grounds of both ideology and efficacy. It adopted a distinctive style and approach which sharply challenged the underlying principles of the post-war settlement (Crouch, 1979), jettisoning any governmental commitment to full employment. Priority was given to policies designed to restrain inflation, to promote individualism and an enterprise culture, to de-regulate the labour market, the privatization of substantial elements of the public sector and the introduction of forms of competition in many remaining areas of public sector services.

There have been substantial changes in the labour market since the late 1970s, with key features being the high levels of unemployment, major changes in the distribution of employment, in the occupational structure and in the composition of the labour force. In broad terms the unemployment rate rose from around two percent in the early 1970 s and four percent in the late 1970s to levels of around ten percent for most of the 1980s and 1990s. (Figures in this section are taken from the Employment Gazette, various issues). The sectoral distribution of labour saw employment in manufacturing fall by almost two million between 1979 and 1984, and with subsequent reductions it now accounts for less than 20 percent of the total. Service sector employment, which is generally lowly unionised, has increased greatly. The number of self-employed grew substantially in the $1980 \mathrm{~s}$, and the absolute total working population rose throughout the decade, reflecting an increase in the proportion of women in the labour force to almost half. Over 40 percent of the ten million women employees had part-time jobs. So-called "male manual" work has greatly diminished; the proportion of employees in "marginal" or atypical forms of employment has greatly increased, and perceived employment insecurity has become much more widespread than in earlier post-war decades. At the same time there have been substantial increases in labour productivity and inflation rates have fallen dramatically from the levels of the later 1970 s and early 1980 s.

Many of these changes are reflected in changes in the workplace. Shifts in the distribution of jobs partially account for the drop in trade union membership from the record high of over 13 million in 1979 to less than nine million. Surveys of industrial relations (e.g. 
Millward et al., 1992) chart the reduced coverage of collective bargaining, and its diminished influence in determining the pay and conditions of employees. There has been a significant shift in the balance of power in favour of employers, and a pronounced managerial emphasis on both the individualisation of employment relationships and on flexibility of employment practices. The de-layering of management, performance related pay, appraisal and a panoply of new employee management practices such as new direct employee communications arrangements and quality initiatives have been introduced - albeit not always successfully (Marchington et al., 1992). The number of large workplaces has fallen. The number of stoppages of work due to industrial disputes has fallen to record low levels.

\section{COLLECTIVE EMPLOYMENT LAW}

The focus in this section is on the changes introduced by successive Conservative Governments led by Mrs Margaret Thatcher (1979-90) and Mr John Major (since 1990) in the legal provisions relating to trade unions, to industrial disputes and some other matters associated with the de-regulation of the British labour market. As indicated earlier, these areas have - by design - been a repeated subject of progressively restrictive legislation over this period, making it one of the most frequently changing areas of statute law. Although there has been an underlying consistency of purpose, the sequential process created by this strategy has added to the complexity of the law and to a degree its uncertainty in some areas. To reflect the process, and to illustrate the developing character of the legislation, the main provisions are summarised chronologically, followed by a brief assessment of the current position.

\section{The Employment Act 1980}

This first Act dismantled some of the provisions of the preceding Labour Government's 1975 Employment Protection Act (EPA) and foreshadowed later developments in relation to strike ballots, picketing, the closed shop and secondary industrial action. For example, it repealed the procedure first introduced in 1975 through which trade unions could refer claims for union recognition to the independent Advisory Conciliation and Arbitration Service (ACAS) for inquiry and report, and (in the event of the failure of the employer to recognise following a valid ACAS recommendation) refer pay and conditions in the firm to the Central Arbitration Committee (CAC) for a binding award. Secondly it repealed Schedule 11 of the EPA through which unions could seek enforceable awards from the CAC where an employer was observing terms and conditions of employment less favourable than "recognised" or "general" levels in the trade or industry concerned. Repeal of the latter removed one of the indirect supports for collective bargaining which had a lengthy history. The Act sought to encourage union postal ballots over industrial action, election of officials etc. by making public funds available for this purpose. The attack on the closed shop began with the introduction of a right "not to be unreasonably excluded or expelled" from a trade union, and of compensation in the event of dismissal for nonmembership if, inter alia, the closed shop had not been approved by a secret ballot majority of 80 percent. It also outlawed certain forms of industrial action aimed at enforcing the 
closed shop. The first steps against secondary industrial action (e.g. sympathy strikes) were taken, confining immunities to situations where there were direct commercial contracts between the employers, and setting other hurdles. The Government took powers to introduce its own Codes of Practice, to be taken into account by courts and industrial tribunals, and subsequently introduced Codes on picketing, the closed shop and (later) on the conduct of industrial action ballots. The Act brought a new definition of lawful picketing, confining this to the employee's own workplace and making secondary picketing unlawful.

\section{The Employment Act 1982}

The principal foci were the closed shop, the legal definition of trade disputes and limiting the legal immunities of trade unions. The Act broadened the circumstances in which dismissal for non-membership of a trade union in a closed shop was to be regarded as unfair and considerably enhanced the compensation payable. The definition of a "trade dispute" - the key to a wide range of trade union immunities - was narrowed to exclude for example inter-union disputes, and to confine it to disputes over a specified list of issues between workers and their own employer. Within this narrower definition the Act made it possible for trade unions themselves to be sued if they were responsible for "unlawful" acts, with maximum awards of damages related to union size. It broadened the range of circumstances in which injunctions could be sought successfully against trade unions by making them liable for any unlawful action organised by their employed officials or committees in the absence of repudiation by a more authoritative body or person. The law on the dismissal of employees participating in industrial action was clarified, removing the possibility of their bringing successful actions for unfair dismissal provided the dismissals were not selective nor made so by selective offers of re-engagement within a three month period.

The Fair Wages Resolutions of the House of Commons (periodically revised after first introduction in the $1890 \mathrm{~s}$ ) obliged government contractors - and in practice most private sector contractors to the public sector - to observe terms and conditions of employment not less favourable than those in collective agreements for that trade or industry, or "the general level". As such they tended to protect unorganised workers and frequently those on low pay. However, this method of extending some minimum provisions of collective agreements to those not party to them threatened to constrain the cost-cutting possibilities of the Government's policy of opening up some directly provided areas of public services to competitive tendering (e.g. school and hospital cleaning, refuse collection). The Fair Wages Resolution was rescinded by the Government in 1983.

\section{The Trade Union Act 1984}

As its name suggests, the Act was principally concerned with the regulation of internal trade union matters (introduced under the slogan of "giving the trade unions back to their members") including the introduction of secret ballots prior to industrial action. In the former area the Act overrode many of the existing arrangements for internal democracy in 
trade unions by requiring that all voting members of union executive committees should be elected every five years by direct secret ballot of members, and gave members rights to complain if disenfranchised to the Certification Officer or through the courts. New provisions were also introduced in relation to unions which, under the 1913 Trade Union Act, had established separate political funds to allow them to spend money furthering political objectives, e.g. financial support of the Labour Party, political campaigns, etc. The Act did not change the existing provisions under which union members contributed separately to a union's political fund nor alter the opting-out arrangement, but required unions wishing to retain political funds to conduct secret ballots of members every ten years. In the event, no such ballot produced a majority against, and several unions which previously did not have a political fund introduced one.

Of wider significance was the Act's provision removing immunity from legal action in cases where trade unions did not hold a ballot before authorising or endorsing a strike or other form of industrial action. Unions were liable for actions by union committees and employed officials (i.e. not those organised or led unofficially by shop stewards), and liability for the former could be avoided if endorsement/authorisation was quickly repudiated in writing by higher authority in the union. Those entitled to vote are all those, and only those, whom it is reasonable for the union to believe will be called on to take action, and the ballot form must not only invite a Yes/No answer but must specify whether the action involves the voter in a breach of his/her employment contract (or interference with its performance). Immunity depends on the ballot demonstrating majority support, and is removed if the ballot is held more than four weeks before industrial action starts. Postal ballots were not compulsory. If a ballot is not held, employers, suppliers or customers who suffer loss through interference with contracts may sue for an injunction to restrain the action and/or for damages.

\section{The Employment Act 1988}

This wide-ranging statute, introduced after the third successive Conservative election victory, again focused mainly on how trade unions operated internally, and was designed to strengthen further the statutory rights of individual union members in various ways. For example, the Act extended the right of those entitled to restrain industrial action without a ballot to those called upon to participate in it. A new publicly-funded Commissioner for the Rights of Trade Union Members was created, with duties including assisting trade union members to bring legal actions against their union, e.g. by paying for legal advice and representation. Following the protracted miners' strike, the Act contained a lengthy list of grounds on which it is unjustifiable for a union to take disciplinary action against members, including most controversially, a right not to be "unjustifiably disciplined" by a union for refusing to take part in industrial action or for crossing a picket line (or encouraging others to do so) even if the action has been supported by a majority in a ballot (the so-called "black legs charter"). There was some fine-tuning of the required conduct of industrial action ballots, with a change to the form of words used on the ballot paper, and in one of the most complex sections, detailed rules regulating the "electorate" in multiestablishment disputes. The Act closed some gateways in the 1980 and 1982 Acts by removing legal immunity protection from industrial action or other pressure to create or 
maintain closed shops. The forms of secret balloting were further prescribed, against the workplace and in favour of the home, by a requirement that ballots concerning Trade Union political funds and elections to union governing bodies must be fully postal, and conducted under the auspices of independent scrutineers.

\section{The Employment Act 1990}

The 1990 Act finally removed all forms of legal protection for the closed shop by providing a right of complaint to an industrial tribunal for anyone refused employment on the ground of non-membership (or membership) of a trade union. Similarly it completed the process started in 1980 by making all forms of secondary action (other than those consequent on peaceful picketing) unlawful. It made unions responsible at law if any official (including non-employees of the union such as shop stewards) called for industrial action. This was the first time the Conservative legislation had directly addressed the important but difficult area of vicarious liability for unauthorised or unofficial industrial action. Union liability for shop stewards' actions in calling or organising industrial action was only removed if senior union officers or committees repudiated the action, without delay, and in the form of written notice of repudiation to individual members, containing the following statement:

Your union has repudiated the call (or calls) for industrial action and will give no support to unofficial industrial action taken in response to it (or them). If you are dismissed while taking unofficial industrial action, you will have no right to complain of unfair dismissal.

The scope of immunities was further tightened by removing immunity for organising industrial action if the action was in support of an employee dismissed for taking part in unofficial action. This was complemented by some greater freedom for employers to dismiss union members who took part in unofficial industrial action by withdrawing their rights to claim unfair dismissal. It further extended the scope of proceedings in which the Commissioner for the Rights of Trade Union members may grant assistance and introduced further requirements to the form and conduct of industrial action ballots.

\section{The Trade Union and Labour Relations (Consolidation) Act 1992}

This consolidating measure introduced no substantive changes, but served the useful purpose of bringing together the currently operative sections of the various enactments relating to collective labour relations, e.g: trade unions and industrial action.

\section{The Trade Union Reform and Employment Rights Act (TURERA) 1993}

The most recent legislation followed the April 1992 election victory of the Major Government, and for a variety of reasons is unlikely to be the last. It introduced an extremely wide-ranging "Citizens Charter" type right for individuals as customers to apply to the High Court for a restraining order against unlawful industrial action, if it does or is likely to delay/interrupt the supply of any goods or services. This radical provision thus 
opened up the possibility, for example, of any consumer in the general public interceding in an industrial dispute, and potentially complicating the employer's management of it, with legal/financial assistance available from a new Commissioner for Protection against Unlawful Industrial Action. It is not confined to the public sector. Extensive changes to industrial action ballots included the stipulation that they must be fully postal, thus perhaps making them more vulnerable to technical challenges (e.g. over inclusion/exclusion of individuals due to mailing lists being slightly out of date). Further, to retain immunities, trade unions were required to give employers seven days notice of holding an industrial action ballot; to enable the employer(s) to identify those being balloted - an early case led to a union being required not just to give categories of employee but to name individuals; show the employer(s) a sample voting slip three days before the ballot and inform the employer of the result as soon as reasonably practicable. Still further statutory obligations were placed on unions seeking to mount lawful industrial action with the requirement, after the ballot, for the trade union(s) to give employers seven days notice of the start of industrial action (effectively a potential "cooling off" period which also allows employers to prepare arrangements to minimise the impact) and to indicate its nature (e.g. one day stoppages or continuous). Independent scrutineers were to be appointed for all industrial action ballots, and required to report within four weeks of the ballot.

TURERA also included a legislative assault on the Trades Union Congress' (TUC's) arrangements for regulating inter-union competition for members (the so-called Bridlington Rules) which had been in place since the 1930s. This was done by introducing a general right not to be excluded or expelled from any trade union, and thus effectively being free to choose to join any union whose rules do not restrict membership to workers employed in a certain industry or occupation. Associated with this, the Act extended the list of member conduct for which unions were prohibited from applying disciplinary sanctions, to include threatening to join another union, refusing to work with non-union members or members of another union etc. Potentially these "freedom of choice" provisions could disturb established recognition agreements, challenge spheres of influence arrangements between unions, and jeopardise single union agreements which had previously been adopted by a number of major overseas companies investing in Britain (e.g. Nissan).

The widespread practice of employers deducting members' Trade Union subscriptions directly from payroll (the "check-off") was also regulated by the Act. Initially the draft Bill proposed to make it unlawful for an employer to do this without the annual written consent of individuals, but following objections from (inter alia) employers pointing to the high administrative costs this was lengthened to every three years. Whilst the government stressed the "protection of individual members" argument, many felt this provision was aimed both at reducing union membership and threatening union finances. A related provision made it unlawful for increased deductions to be made unless the employer had notified the worker of the increase at least one month in advance and reminded the worker of his/her right to withdraw authorisation at any time. Again this provision was seen by some as a deterrent both to employers continuing check-off arrangements (due to costs and vulnerability to legal challenge) and to unions raising subscription levels. Since the passage of the Act several unions have sought to persuade members to switch to standing orders/direct debits from personal bank accounts. However, it seems inevitable that the Act's provisions will lead to some reduction in union membership. The Certification Officer's powers on trade union finances were further extended, and there were further 
regulations on TU membership registers, election of officers, ballots on union mergers and political fund ballots. Finally the Act removed the duty "to encourage the extension, development and reform of collective bargaining" (set out in the 1975 EPA) from ACAS's general duty to promote the improvement of industrial relations, and also gave the Secretary of State a reserve power to require ACAS to charge for certain services.

\section{Assessment}

Although they were interventionist, contrary to long-established traditions and were vehemently opposed by the unions, there is no doubt that much of the early legislation commanded widespread public support, especially that limiting picketing and requiring preindustrial action secret ballots. Initially there were some instances of unions refusing to observe certain provisions, leading to injunctions and sequestration of union assets in a few cases, but the majority of unions quickly saw the dangers of direct challenges to the law and pinned their faith in the election of a Labour Government which they hoped would modify - if not abolish - the new laws. However, conscious of the electoral dangers of such a commitment, the Labour Party was - and remains - cautious. There is little doubt that many of the provisions will continue under a future Labour Government, even if there are amendments to the details, and possibly extension of some principles to other areas, e.g. company donations to political parties.

The impact of the measures is difficult to gauge. The Conservatives are not inclined to minimise this, frequently declaring the waning of union power, the assertion of statutory rights for members, and the diminution in strikes as directly attributable to the legislation. Indeed these claims feature prominently in the Government's periodic assessments of its own achievements, and retaining the issue of "trade union reform" prominently on the political agenda (and a point of contrast to the Labour Party) may produce further Conservative legislation in the future. If so, this could include the introduction of "repeat" ballots in instances of lengthy industrial action and possibly attaching legal enforceability to the procedural sections of collective agreements. Other commentators argue that the assessment of impact is less simple, and point to the high levels of unemployment, fears about job security, the switch from heavily unionised to lowly unionised sectors of employment, declining union membership and other changes as contributory factors in the reduction of union power and strike frequency.

In sharp contrast to the 1970 s and early 1980 s recent public opinion polls are reporting increasingly positive perceptions of unions, with many fewer people regarding them as too powerful. Indeed, there are strong currents of opinion, including those of some employers, that some of the more recent legislation has gone too far, that it is becoming dysfunctional to the efficient conduct of industrial relations and appears to be targeted in a far from even-handed way at deterring union membership and industrial action to a point which is either unnecessary or undesirable in a free society. Some elements of the more recent legislation (e.g. the so-called black legs charter provision in the 1988 Act, and the citizens' rights, the anti-Bridlington provisions and the check-off regulations) fall into this category. The principle of strike ballots remains popular, but there is a feeling that the frequent alteration of the details reflects governmental disappointment with the actual outcomes of 
them. Whilst comprehensive statistics are not available, the evidence, e.g. ACAS Annual Reports, suggests that the great majority of ballots support industrial action, which can often assist the union side in collective bargaining. The increasingly complex statutory prescriptions about the conduct of ballots are held by some to be now so detailed and so onerous as to make it extremely difficult to conduct an industrial action ballot lawfully due to the risk of injunctions on technicalities. Indeed, some suggest that the present provisions are actually designed to deter ballots, and therefore lawful industrial action! At the same time the threat of legal actions has fostered increased control by union head offices over local stoppages and other forms of action (see Martin et al., 1991). Despite the copious new rights for employers, for union members, for customers and others established by the various statutes, the level of litigation has remained surprisingly low and has mainly been concentrated in a few sectors (see Evans, 1987). This may stem from a variety of factors, including widespread union compliance and a continuing disinclination of employers and others to regard going to the courts as a useful avenue in all but the most trying of circumstances. Where recourse has been made to the legal process in collective matters the principal objective appears to have been interim injunctions - which in general the courts have been ready to grant. Very few cases indeed have proceeded to full hearings and awards of damages.

\section{INDIVIDUAL EMPLOYMENT LAW}

\section{Shrinkage of employment protection rights}

Some individual employment rights also suffered erosion during the years of Conservative rule, though in part this is due to developments in the labour market which saw a growth in "marginal" workers falling outside the net of employment protection. The statutory rights enacted in the 1970s had never been of general application. Their coverage was based very largely on the "standard" relationship of full-time permanent employment, being dependent upon a qualifying period of continuous employment of at least 16 hours per week for a period of two years. This period was extended to five years in the case of parttimers working between eight and 16 hours per week.

The 1980s saw a major restructuring of the labour market involving an increase in nonstandard forms of employment. Many reasons have been put forward for this shift away from the standard, full-time contract. Some have attributed it to changes in product markets and technological conditions, whilst others have seen it as a response to policies of deregulation or simply as being linked to the increase in married women with children entering the labour market. Whatever the explanation, the number of jobs of indefinite duration fell by 1.1 million from 70 percent to 64 percent of total employment between 1981 and 1987 and were in effect "replaced" by a 1.7 million increase in non-standard jobs (Hakim, 1990). In consequence, the coverage of employment protection was proportionately reduced, so that by 1987 , it was being claimed that at least a third of workers fell outside basic labour law rights (Leighton and Painter, 1987).

One form of non-standard employment which showed a strong and persistent growth rate over this period was self-employment, with a rise in numbers from 2.2 million to 3.3 
million between 1981 and 1991 (Campbell and Daly, 1992). Yet one million of the increase was accounted for by "sole-traders", some of whom exhibited degrees of dependency which would bring their self-employed status into question. However, the judicial response to classification of these workers has been variable. Thus in Nethermere (St Neots) Ltd v Gardiner and Taverna ((1984) IRLR 240), the Court of Appeal acknowledged the dependency of female homeworkers employed in unskilled work and looked to the "economic realities of the situation" in designating them employees. In contrast, regular casual workers whose only source of income derived from working in the banqueting department of a large hotel chain, who were subject to the authority of the banqueting manager and who could be penalised for refusing work, were regarded as selfemployed (O'Kelly v Trusthouse Forte (1983) ICR 728). On this occasion the Court of Appeal took a theoretical approach to the obligation by the parties to offer and to accept the work, and were influenced by the custom and practice in the industry of regarding casual workers as self-employed.

The erosion in employment protection through labour market developments was accompanied, from the time the Conservatives returned to power in 1979, by specific amendments to the legislation. They began by immediately doubling the service qualification for unfair dismissal from six months to 12 months (SI 1979 No 959), and the following year the Employment Act 1980 was passed. In pursuance of a recurring theme that special protection should be given to the small employers regarded as vital to wealth creation, it further extended the unfair dismissal service qualification to two years, and reduced maternity rights, in businesses employing less than 20 employees. The number of those excluded from the right to claim unfair dismissal was also increased by providing that such rights could henceforth be waived in a fixed term contract of one year or more, as opposed to the previous requirement of at least two years. Provisions related to industrial tribunal procedure shifted the burden of proving "reasonableness" from employers in unfair dismissal cases, and required tribunals specifically to take account of the size and administrative resources of the employer's undertaking in deciding whether an employer had acted reasonably.

In 1985 the longer qualifying period for unfair dismissal claims was applied to all employees by the then Chancellor of the Exchequer's "Budget for Jobs", on the apparent premise that this would encourage employers to recruit more freely and hence lead to an increase in jobs. Nine years on, this amendment has been challenged by two women as being indirectly sex discriminatory $(R v$ Secretary of State for Employment, ex parte Seymour-Smith and Perex (1994) IRLR 448.) Though the women were unsuccessful, it is interesting to note that the Divisional court rejected the claim that the raising of the qualifying threshold from one to two years has had a notable effect in promoting the creation of job opportunities. Mr Justice McCullough stated that "if the changes (to the qualifying period) had to any significant extent increased opportunities for employment I would have expected that by 1994 hard evidence of this would have been presented to the court."

In addition to the strategy of seeking to reduce labour costs by attacking employment rights, the government also brought about changes to reduce directly the primary ingredient of labour costs, namely wages. The Wages Act 1986 weakened the power of Wages Councils, which had existed since 1909 and established minimum wages, holidays and other basic 
terms and conditions in low paying industries such as the hotel and catering industry. It also removed employees aged under 21 from their scope, on the basis that to regulate the pay of young people acted as a disincentive to their recruitment. The subsequent abolition of the Councils by the Trade Union Reform and Employment Rights Act 1993 has now removed 2,500,000 workers from statutory minimum wage-fixing machinery. Moreover it is argued (see e.g. Hendy, 1993; Wilkinson \& Deakin, 1991) that the government's strategy of reducing wages as an element of labour costs is dangerous because: "A low wage policy tends to produce a low skill, high turnover, low productivity and poorly managed workforce." (Hendy, 1993:32).

\section{Effect of European law}

In almost direct opposition to the Conservatives' policy of deregulation, the European Community (now European Union) has increasingly highlighted its "social dimension" by introducing directives aimed at increasing the statutory protection of employed people. As would be expected the United Kingdom government set its face against such moves and consistently blocked directives introduced during the 1980s such as those on parental leave, the burden of proof in discrimination cases and worker participation. In 1989 the United Kingdom alone among the 12 member states refused to sign up to the Community Charter of the Fundamental Social Rights of Workers (The "Social Charter"), and later very overtly distanced itself from the Community's attempt to move forward towards implementation of the aims of the Social Charter by negotiating a United Kingdom opt-out from the Protocol to the Social Chapter of the Maastricht Treaty in 1991.

Though the United Kingdom may not be bound in the future by new Community legislation in this area, existing directives cannot be side-stepped. They must be implemented by member states so as to achieve the result intended by the directive. Yet the United Kingdom's grudging attitude towards compliance has led repeatedly to accusations of failure to implement directives fully, and the government has been obliged to comply by amending the relevant legislation. Thus the Equal Pay (Amendment) Regulations 1983 were the government's hasty and much-criticised attempt to implement the concept of "equal pay for work of equal value" demanded by the Equal Pay Directive (75/117) following infringement proceedings brought by the European Commission (Commission of the European Communities $v$ United Kingdom of Great Britain and Northern Ireland (1984) IRLR 29). Similarly, the Sex Discrimination Act 1986 was the government's response to the allegation that, by failing to outlaw sex discrimination in retirement ages, and by excluding employers with five or fewer employees from the scope of the Sex Discrimination Act 1975, it was in breach of the Equal Treatment Directive (76/207). More recently, the statutory ceiling (of $£ 11,000$ ) on compensation in sex discrimination claims has also been held to breach this Directive, and it was removed in 1993 by the Sex Discrimination and Equal Pay (Remedies) Regulations (legislation to amend similarly the Race Relations Act 1976 followed shortly afterwards).

Even legislation passed specifically to implement Directives has been found wanting and required subsequent amendment. Based on five heads of complaint, the European Court of Justice (ECJ) recently declared that the United Kingdom government had failed to fulfil 
obligations arising from the Acquired Rights Directive (77/187) despite its attempt to do so by means of the much litigated Transfer of Undertakings (Protection of Employment) Regulations 1981 (see eg Napier, 1993). The subject matter of four of the complaints had, by the time of the judgment, been rectified by specific sections of the Trade Union Reform and Employment Rights Act 1993, but the remaining matter outstanding is of some significance. The Directive had required representatives of employees affected by a transfer of an undertaking to be informed and consulted about it. The ECJ was unmoved by the United Kingdom's argument that the Directive could not have been intended to undermine the principle of "voluntary recognition" of trade unions, and found that in failing to provide a mechanism for the designation of employee representatives in an undertaking where no union was recognised the United Kingdom government was in breach.

It would not be surprising if the United Kingdom were again to do the minimum required, by establishing machinery simply to deal with business transfers (and redundancy, since there was found to be a similar breach of the Collective Redundancies Directive, 75/129). That was certainly the approach taken when faced with the Directive on the Safety and Health of Pregnant Women at Work (92/85). In implementing the Directive, the government was faced with two constraints, first that it could not lessen existing maternity rights, and secondly that it had to provide for a minimum maternity leave period of 14 weeks. In simply complying with these requirements and no more, the outcome has been an extraordinarily complex dual system which has one set of provisions for those women who have over two years service and another for those who have not. It seems extremely unlikely that even the most able women workers will find it easy to enforce their rights at a time when they will have priorities other than the interpretation of statutes.

Although this "incoming tide of EC labour law" (Ewing, 1993) has increased individual employment rights in the United Kingdom, it is not the only way in which Community law has exerted a profound influence over domestic law. Bold judgments by the ECJ on the interpretation and scope of Article 119 of the Treaty of Rome have expanded what may legitimately be regarded as "pay" and therefore subject to the principle of sex equality. Undoubtedly the most striking of these was the ruling in the Barber case (Barber $v$ Guardian Royal Exchange Assurance Group Ltd (1990) IRLR 240) that occupational pensions were "pay" for the purposes of Article 119, a ruling which caused turmoil throughout the pensions industry. Recognising that the overwhelming majority of part-time workers are women, the court has also increasingly regarded unfavourable treatment of parttime workers as indirect discrimination on the grounds of sex, and unless justified, contrary to the Equal Pay and Equal Treatment Directives.

At the heart of the debate over part-timers' rights are the provisions of the domestic legislation which excluded them totally from employment protection if fewer than eight hours per week were worked, and required a five year qualifying period if the hours of work were between eight and sixteen. In 1994, the Equal Opportunities Commission claimed a major victory by successfully challenging this legislation in the courts by way of judicial review ( $R v$ Secretary of State for Employment, ex parte EOC (1994) IRLR 493). In defending the claim, the Secretary of State did not challenge the discriminatory effect of the law, but fell back once more on the well-worn argument that the purpose of the qualifying thresholds was to bring about an increase in availability of part-time work. Whilst accepting that to increase part-time work was an acceptable aim, the House of Lords 
ruled that reducing the costs to employers of employing part-time workers was not a suitable way of achieving such an aim. Moreover there was an outright rejection of the Secretary of State's "evidence" that the threshold provisions had actually achieved their stated aim. In the words of Lord Keith:

The evidence for the Secretary of State consisted principally of an affidavit by an official in the Department of Employment which set out the views of the Department but did not contain anything capable of being regarded as factual evidence demonstrating the correctness of these views.

Though the outcome of the case for the government is again an obligation to amend its legislation, dismissed part-time workers need not await this. Because the Employment Appeal Tribunal has declared that unfair dismissal is, like redundancy pay, to be regarded as pay for the purposes of Article 119 (Mediguard Services Ltd v. Thame (1994) IRLR 504 ), individuals may simply rely on their directly enforceable rights under this Article (see e.g. Warren and Wylie (1994) IRLR 316).

\section{Assessment}

Several distinct themes have emerged in examining legal developments in the United Kingdom since 1979. The most notable in terms of individual labour law has been the tension between the government's moves towards deregulation and the reducing the "burdens on employers", and the drive by European Community lawmakers towards increased protective regulation. At present the United Kingdom government shows no sign of altering its stance. It has voiced its opposition to draft directives on Parental Leave, on Temporary Workers and on Young People in Employment, and having swept away the remaining protective legislation on working hours of women and young people in the Employment Act 1989, is now challenging the legal basis of the Working Time Directive. (This was introduced as a health and safety measure and thus under EU procedures requires only qualified majority voting in order to be adopted).

Challenges continue to legislation which arguably does not fully implement community obligations. Because of the complexity of the equal value legislation and the inordinate length of time taken by some cases to proceed through the legal route (see e.g. British Coal Corporation v Smith and others (1994) IRLR 342) the Equal Opportunities Commission is now alleging a breach of Article 119 and the Equal Pay Directive. The TUC has also lodged a formal complaint with the European Commission, arguing that the abolition of the Wages Councils will in particular leave many women in low-wage industries with no effective means of redress against unlawful reductions in their wages (TUC, 1993).

On the collective front the government has sharply reduced trade union immunities, and outlawed some union practices such as the closed shop and secondary industrial action. It has repeatedly added further statutory pre-requisites on unions prior to lawful industrial action and progressively broadened the categories of people who can seek injunctions against strikes that may not satisfy the detailed criteria for legality. Vicarious liability for unauthorised actions, e.g. by workplace representatives and unofficial strikes, has been attached unambiguously to the unions. The government has also been heavily interventionist in union internal affairs, and established many statutory rights for union 
members. These are backed by two new Commissioners empowered to assist, with financial and legal support, those seeking to bring legal actions against trade unions. Other than in connection with race and sex discrimination, similar support from public funds or agencies is not available to employees wishing to complain of breach of their statutory rights. No obstacles have been placed in the way of employers wishing to de-recognise unions. Indeed, the Conservatives' preference for individual negotiation rather than collective bargaining or statutory regulation was clearly demonstrated by the mechanism chosen for reform of the antiquated Truck Acts by the Wages Act 1986. In addition to removing the right to cash pay, the Act stripped away blanket prohibitions on deductions from wages, and replaced them by provisions permitting deductions via contractual "agreement".

If one piece of legislation can be said to encapsulate the themes which have emerged over the last 15 years, it is the Trade Union Reform and Employment Rights Act. In its insistence on additional requirements for lawful strike ballots, its assault on the Bridlington Rules and the new conditions for operating check-off systems, it can certainly be seen as placing obstacles in the paths of trade unions and potentially damaging trade union membership. One section particularly worthy of note is section 13 , which was added very much at the eleventh hour as a response to the Court of Appeal's decision in the cases of Wilson $v$ Associated Newspapers Ltd and Palmer and another $v$ Associated British Ports (1993) IRLR 336. The Court of Appeal had held that an employer who offered a financial inducement to employees to abandon collectively-bargained pay and conditions in favour of so-called "personal contracts" was acting unlawfully, since this amounted to discriminatory treatment against those who refused to sign, in order to deter them from union membership. Although one purpose of the employer's action was simply to move away from collective bargaining, the Court held that a second purpose was to create a situation where the union "withered on the vine". In effect, section 13 now requires that the second (unlawful) purpose must be disregarded unless a tribunal takes the view that no reasonable employer would have acted in the way he or she did in order to alter employment relationships.

In marked contrast, the Act also embodies the requirements of no fewer than five EC directives. In addition to making the required amendments on transfers of undertakings and redundancy and granting new maternity rights, provisions originating in a health and safety directive of 1989 give new protection against dismissal and other detrimental treatment where workers take action believing that their health and safety is in imminent danger. Implementation of the Proof of Employment Relationship Directive also improves the rights of temporary workers by providing for written particulars of employment within two months of employment rather than 13 weeks. As a whole the Act will bring some protection for many "marginal workers" because its new unfair dismissal rights will apply regardless of hours of work or length of service.

Though life may have been relatively quiet on the collective litigation scene the same cannot be said for applications to enforce individual rights. In 1990/91 the number of cases disposed of by industrial tribunals was 35,826 ; by $1992 / 93$ this had risen to 53,445 (Employment Gazette, November 1993). Given the new individual rights in the 1993 Act and the long-awaited jurisdiction over breach of contract claims first enacted in the Employment Protection Act 1975 but never exercised, it seems reasonable to predict that 
the work of the tribunals is set to increase still further. It also seems reasonable to predict that whatever be the policies of the government in power in the foreseeable future, the role of the law is unlikely to diminish.

\section{References}

ACAS Annual Reports, 1985 et seq, London, HMSO.

Campbell, M. and Daly, M. (1992), Self-Employment: Into the 1990s, Employment Gazette, June: 269.

Crouch, C. (1979), The Politics of Industrial Relations, London, Fontana.

Employment Gazette, various issues, London, Department of Employment.

Evans, S. (1987), The Use of Injunctions in Industrial Disputes, British Journal of Industrial Relations, 25: 419-35.

Ewing, K.D. (1993), Swimming with the Tide: Employment Protection and the Implementation of European Labour Law, Industrial Law Journal, 22(3): 165.

Hakim, C. (1990), Core and Periphery in Employers' Workforce Strategies: Evidence from the 1987 E.L.U.S Survey, Work, Employment and Society, 4(2): 157.

Hendy, J. (1993), A Law Unto Themselves. Conservative Employment Laws: A National and International Assessment, Institute of Employment Rights, London.

Marchington, M.; Goodman, J.; Wilkinson, A. and Ackers P (1992), New Developments in Employee Involvement, London, Employment Department Research Series No. 2.

Martin. R.; Fosh, P.; Morris, H.; Smith, P. and Undy, R. (1991), The De-collectivisation of Trade Unions? Ballots and Collective Bargaining in the 1980s, Industrial Relations Journal, 22: $197-208$.

McCarthy, W. (ed.), (1992), Legal Intervention in Industrial Relations: Gains and Losses, Oxford, Blackwell.

Millward, N.; Stevens, M.; Smart, D. and Hawes W.R. (1992), Workplace Industrial Relations in Transition, Dartmouth, Aldershot.

Leighton, P. and Painter, R. (1987), "Who are Vulnerable Workers?", Employee Relations, 9(5), 3-8. 
Napier, B. (1993), CCT Market Testing and Employment Rights; the effects of TUPE and the Acquired Rights Directive, London, Institute of Employment Rights.

Trades Union Congress (1993) Complaint to the Commission of the European Community for failure to comply with Community Law 89/C26/07. 